\title{
RANKING OF OFFICE LEASE OPTIONS BY MULTI-CRITERIA METHODS
}

\author{
ROMUALDAS GINEVIČIUS, TOMAS GINEVIČIUS, \\ DAINORA GEDVILAITE், ANDRIUS STASIUKYNAS
}

Corresponding author:

Romualdas Ginevičius

Bialystok University of Technology, Faculty of Management, Department of Business Informatics and Logistics,

Poland

e-mail: romualdas.ginevicius@vgtu.It

Tomas Ginevičius

\section{A B STRACT}

Due to the growing scales of business and internationalisation, the issue of the office lease is becoming more and more relevant for companies. They are becoming an inherent part of business, on which the results of the commercial activity depend. Currently existing methodologies for the assessment of the office lease options are imperfect as they lack complexity; they are not associated with the objective of the lease - the improvement of the business results; the methods of the quantitative assessment of lease options are far from perfect. The paper aims at formulating the hierarchical indicator system of commercial real estate facilities (offices) adjusted for the multi-criteria assessment and at calculating the lease options based on this indicator system. To achieve this goal, the following methods have been used: scientific literature analysis and multi-criteria assessment methods.

KEY WORDS

lease of commercial facilities (offices), forming the indicator system, multi-criteria assessment methods

DOI: 10.1515/emj-2016-0036
Technical University, Vilnius Gediminas Technical University, Lithuania

e-mail: tomas.ginevicius@vgtu.lt

Dainora Gedvilaitè

Vilnius Gediminas Technical University, Business Management Faculty, Lithuania

e-mail: dainora.gedvilaite@vgtu.It

Andrius Stasiukynas

Vilnius Gediminas Technical University, Business Management Faculty, Lithuania

e-mail: andrius.stasiukynas@vgtu.It

\section{INTRODUCTION}

The business trend analysis shows that the gradually increasing demand for offices derives from both internal and external needs. The former appear where the companies establish their affiliates and subsidiaries, expand their business in new areas, want to improve the office environment and focus their activities on one space. The external demand is the need for offices among foreign companies that invest in the country. The global investors currently optimising their business are increasingly interested in the Middle Europe and the Baltic States, and they are gradually turning away from India and Asian countries. Consequently, the demand for offices will continue to grow. 
Recently, an office has been considered an important factor affecting the business results. Therefore, the premises for rent are subject to more stringent requirements regarding technical characteristics, quality and variety of offered services, working environment, etc. (French \& Wisemann, 2003; Nase et al., 2013; Pagourtzi et al., 2003; Ginevičius et al., 2004; Zhang, 2015). Consequently, the potential tenant, when selecting the premises, considers the aggregate of criteria covering various aspects. It depends on a place (Alonso, 1964; Muth, 1969; Mills, 1972; DiPasaquale \& Wheaton, 1992; Dunse \& Jones, 1998; French \& Wiseman, 2003; Pagourtzi et al., 2003; Čeh et al., 2012; Nase et al., 2013), year of built and architectural solutions (Wagner et al., 2014; French \& Wiseman, 2003; Pagourtzi et al., 2003; Nase et al., 2013), engineering infrastructure (Dunse \& Jones, 1998; Ncube \& Riffat, 2012), car parking facilities (Nase et al., 2013; Wagner et al., 2014), additional services provided (Peng et al., 2014; Wagner et al., 2014), level of fit out at the premises (Nase et al., 2013; Khamkanya et al., 2012; French \& Wiseman, 2003, Pagourtzi et al., 2003), external environment (Nase et al., 2013; Čeh et al., 2012).

In this case, the office lease options are defined by multiple various indicators. Phenomena manifesting through various aspects of reality are

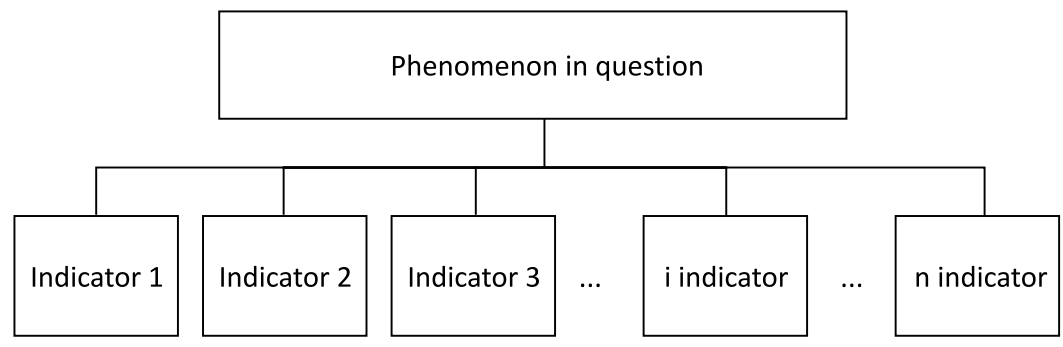

Fig. 1. Single-level indicator system tors are included in the system, the more thoroughly the phenomenon in question is reflected, and vice versa, the fewer indicators are included in the system, the greater is a threat that the significant indicators will not be assessed and the assessment of the status of the phenomenon in question will seem inadequate; second, the more indicators are included in the system, the more indicators will be difficult to formalise; moreover, the system will become complicated, and it will be hard to accurately determine weights of the indicators, which will result in higher calculation costs and lower accuracy.

The formation of the indicator system starts with the list compilation. The objective of formation of the system itself is an adequate reflection of the phenomenon in question and its adjustment for the multicriteria assessment. The content and result of this process depend on how many indicators are included in the system. Where there are a few indicators, the single-level indicator system is formed (Fig. 1). attributed to complicated and complex ones. Such phenomena may only be recognised when assessing all criteria reflecting such a phenomenon as a whole. This is where the criteria-based approach of the office lease comes from as a phenomenon. The multi-criteria methods are most eligible for the assessment.

\section{FORMATION OF THE INDICATOR SYSTEM OF OFFICE LEASE OPTIONS}

The essential stage of the multi-criteria assessment is the formation of the indicator system of the phenomenon in question. This is because the adequacy of reflecting the phenomenon in question largely depends on its completeness and structure. When forming such a system, the following statements are usually referred to (Ginevičius et al., 2004; Ginevičius \& Podvezko, 2005): first, the more indica-
The use of such an indicator system for the multicriteria assessment of complicated complex phenomena is rather limited as in this case, it is subject to an intractable issue related to the indicator significance determination. This means that the experts may somewhat accurately assess the weights of a limited number of indicators only. The proposed complicated approaches to determine the significance of indicators do not fully resolve this problem as well (Saaty, 1980). According to the references, without greater evidence, however, this number equals 10-12 (Ginevičius, 2009). When looking for a solution, it is necessary to find a method enabling to reduce the number of simultaneously assessed indicators. This problem may be resolved by means of hierarchical structuring of the indicator system, which enables the reduction in the number of simultaneously assessed indicators to the preferred number (Ginevičius, 2007a, 2007b, 2009).

Based on this methodology, the following hierarchically structured system of indicators of the office 
lease options was formed (Fig. 1). It consists of 51 indicators; all of them are divided into three blocks by affinity, i.e. economic, environmental, and premises. The number of indicators in some of the main blocks (environmental and buildings) appeared to be too high in terms of the weight assessment; therefore, based on the principles of affinity again, they were divided into several parts: the block of environmental indicators - into infrastructure and location, and buildings - into the level of technical layout, atmosphere and options (Fig. 2).

\section{Multi-CRITERIA ASSESSMENT OF THE OFFICE LEASE INDICATOR SYSTEM}

First of all, the method of carrying out the multicriteria assessment of the hierarchically structured indicator system needs to be discussed. To carry out such an assessment, the weights and values of all indicators of the hierarchical level must be known.

The determination of the indicator weights starts from the lowest level of the hierarchical structure. This is done in two stages. Firstly, the experts set the indicator ranks for each group of the indicators of this level (in our case, there are six groups). This helps the experts to express a more uniform opinion when it comes to the assessment of the indicator weights. As the number of indicators in each group does not exceed 12 , their weights may be determined directly, i.e. by distributing 1 among the indicators subject to assessment.

$$
\text { It is presumed that } \sum_{i=1}^{n} w_{i}=1
$$

where:

- $\quad w_{i}-\mathrm{i}$-th indicator weight, $\mathrm{n}-\mathrm{a}$ number of indicators, $i=\overline{1, n}$ ).

When the weights of the indicators of the lowest level of the hierarchical indicator system are determined, the weights of the higher-level indicators must be determined. As shown in Fig. 1, this level contains two environmental blocks and three premise indicator blocks. Their weights are determined in the same way as in the previous case.

Similarly, the weights of three main indicator blocks (economic, environmental, and premises) are determined. In all cases, the indicator weights were determined directly, i.e. the experts had to distribute parts of 1 among the indicators subject to assessment, where weights were equal to one.
When the weights of the hierarchical structure indicators are determined, their values must be set. A further complication is that a part of them is expressed in measurable dimensions, i.e. per cent, units, euro, metres, etc., and others belong to the hardly formalised ones, i.e. the ones that cannot be measured, for instance, prestige of the location, view through the office windows, the administration procedure, etc. In such cases, the only way to attribute values to such indicators is per expert assessment.

Lease options differ not only in economic (price, contract terms and conditions, etc.), environmental (prestige of the location, geographical location, communications, etc.) and premise (technical layout, arrangement, lighting, etc.) indicators, but also in their nature as some of them are maximising (the situation improves with the increasing indicator value) and other indicators are minimising (the increasing value leads to the worsening of the situation). The multi-criteria assessment method SAW, which was applied when determining the priorities of the lease options, requires the uniformity of changes in the indicators, i.e. all of them must be either maximising or minimising. The maximisation of minimising indicators is carried out as follows (Hwang \& Yoon, 1981):

where:

$$
q_{i j \max }=\frac{q_{j \min }}{q_{j}}
$$

- $\quad q_{i j \max }$ - the maximised value of the $\mathrm{i}$-th indicator of the $\mathrm{j}$-th variant,

- $q_{i j}$ - the value of the i-th indicator of the $\mathrm{j}$-th variant,

- $\quad q_{i j \min }$ - the lowest possible value of the i-th indicator of the $j$-th variant.

The minimisation of indicator values is carried out as follows (Hwang \& Yoon, 1981):

$$
q_{i j \min }=\frac{q_{j}}{q_{j \max }}
$$

where:

- $\quad q_{\ddot{g} \min }$ - the minimised value of the i-th indicator of the $\mathrm{j}$-th variant,

- $q_{i j \max }$ - the highest possible value of the i-th indicator of the $j$-th variant.

The lease options are expressed in different dimensions; therefore, they cannot be combined in one generalised unit. They are converted into nondimensional ones through the value standardisation (Podvezko 2008): 


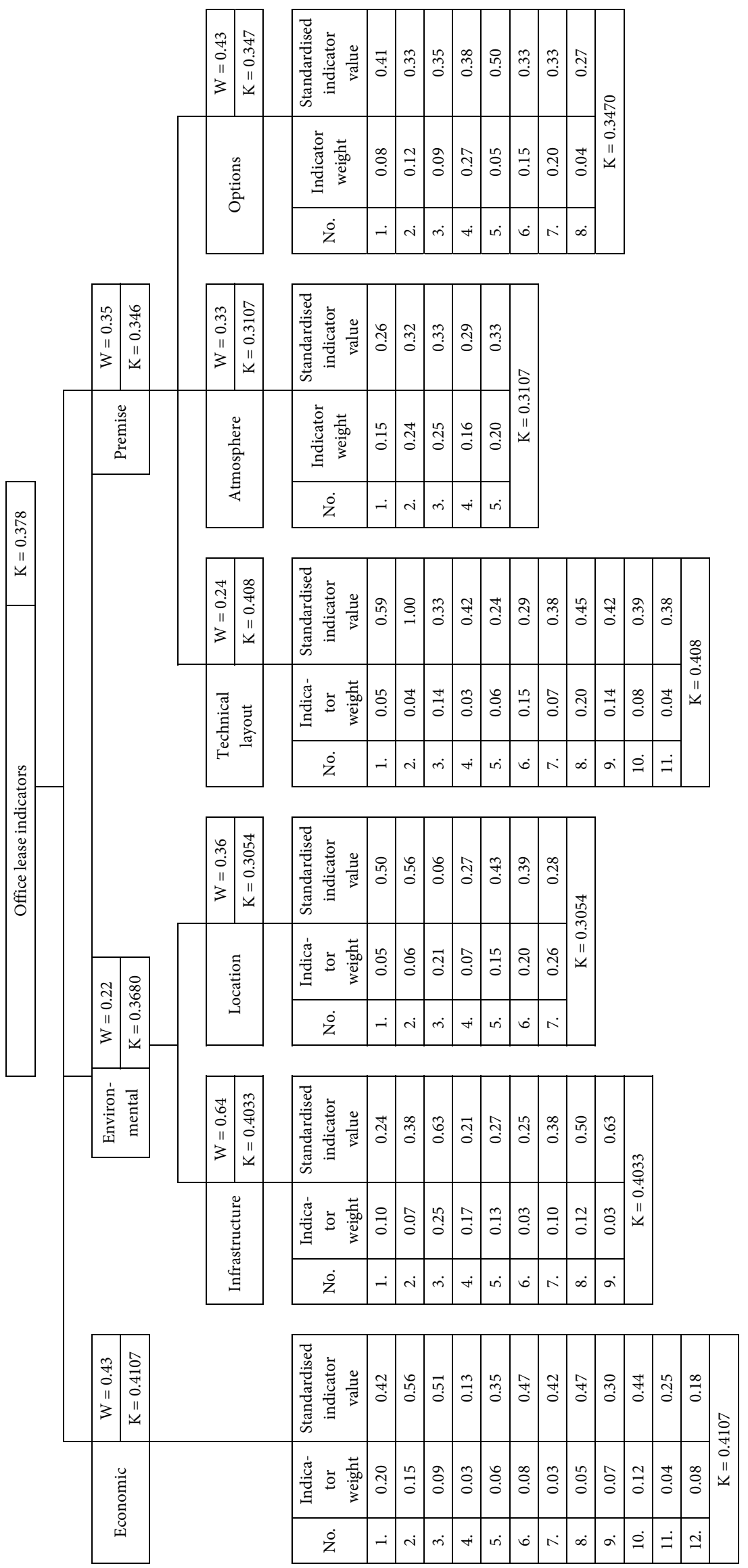




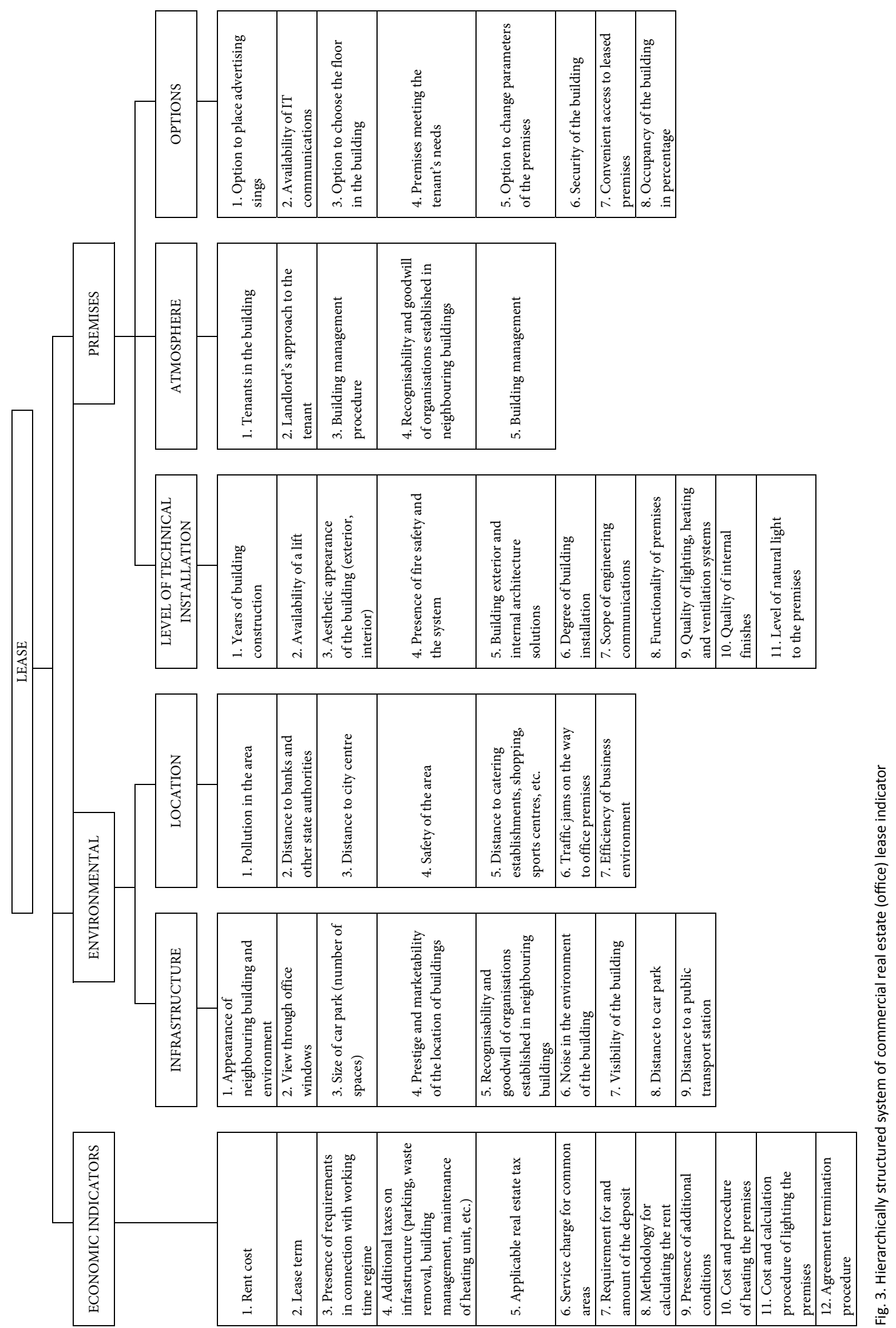




$$
\widetilde{q}_{i j}=\frac{q_{j}}{\sum_{i=1}^{n} q_{j}}
$$

where:

- $\tilde{q}_{i j}$ - the standardised value of the i-th indicator of the j-th lease option,

- $\mathrm{n}-$ a number of indicators $(i=\overline{1, n})$.

The multi-criteria assessment of the hierarchical indicator system of the lease options was carried out by means of the method SAW (Hwang \& Yoon, 1981):

where:

$$
K_{j k}=\sum_{i=1}^{n} w_{j i k} \widetilde{q}_{j i k}
$$

- $K_{j}$ - the value of indicator system of multi-criteria assessment through SAW of the k-th indicator group of the $\mathrm{j}$-th hierarchical level,

- $w_{j i k}$ - the weight of the $\mathrm{i}$-th indicator of the $\mathrm{k}$-th indicator group of the $\mathrm{j}$-th hierarchical level,

- $\widetilde{q}_{j i k}$ - the standardised value of the $\mathrm{i}$-th indicator of the k-th indicator group of the $j$-th hierarchical level.

\section{RANKING OF OFFICE LEASE OPTIONS BASED ON THE HIERAR- CHICAL SYSTEM OF INDICATORS}

The multicriteria assessment of hierarchically structured system of indicators is bottom-up, i.e. it starts at the bottom level in the hierarchy. Following formulas (1-3), the weights and normalised values of all six groups of related indicators are determined (Fig. 3).

Based on Table 1, the following values of the third-level multicriteria assessment of the lease of a commercial real estate object (office) have been obtained.

These values immediately become the same of the units combining the above groups of indicators and positioned on a higher level of the hierarchical structure (infrastructure, location, level of technical installations, ambience, and options).

To perform a second-level multicriteria assessment of the hierarchical structure, one needs to know the weights of the environmental and premises groups of indicators. Following the expert survey, it has been obtained that the weights of groups of environmental indicators (infrastructure and location) equal 0.64 and 0.36 , respectively; whereas the same of groups of premises indicators (level of technical installations, ambience, and options) are 0.24 ; 0.33 and 0.43 , accordingly. Based on Table 1 and the weights determined, the following results of the multicriteria assessment for the second-level indicators have been obtained for the lease of a commercial real estate object (office), (Table 2).

The values of the multicriteria assessment of the first-level economic indicators (Table 1) and the second-level environmental and premises indicators (Table 2) of the hierarchical system of indicators are the values of the key units (economic, environmental, and premises) of the system of indicators. To carry out the final multicriteria assessment of lease options, one needs to know the weights of the above units. Following an expert evaluation performed, it has been obtained that the above weights equal $0.43,0.22$, and 0.35 , respectively.

Following the multicriteria assessment, the following results have been obtained (Table 3 ).

It is evident in the multicriteria assessment of three lease options carried out based on the hierarchically structured system of indicators that such assessment calls for many calculations. The scope will significantly increase if there are many options to be

Tab. 1. Results of multicriteria assessment of the third-level indicators of the lease of a commercial real estate object (office) using the

\begin{tabular}{|c|c|c|c|c|c|c|c|c|c|c|c|c|c|c|c|c|c|c|}
\hline \multirow{4}{*}{$\begin{array}{l}\text { NAME OF } \\
\text { INDICATOR } \\
\text { GROUP }\end{array}$} & & & & \multicolumn{6}{|c|}{ ENVIRONMENTAL } & \multicolumn{9}{|c|}{ Premises } \\
\hline & \multicolumn{3}{|c|}{ ECONOMIC } & INF & STRL & URE & \multicolumn{3}{|c|}{ LOCATION } & \multicolumn{3}{|c|}{$\begin{array}{c}\text { LEVEL OF TECHNI- } \\
\text { CAL INSTALLA- } \\
\text { TIONS }\end{array}$} & \multicolumn{3}{|c|}{ AMBIENCE } & \multicolumn{3}{|c|}{ OPTIONS } \\
\hline & \multicolumn{3}{|c|}{ ALTERNATIVES } & \multicolumn{3}{|c|}{ ALTERNATIVES } & \multicolumn{3}{|c|}{ ALTERNATIVES } & \multicolumn{3}{|c|}{ ALTERNATIVES } & \multicolumn{3}{|c|}{ ALTERNATIVES } & \multicolumn{3}{|c|}{ ALTERNATIVES } \\
\hline & 1 & 2 & 3 & 1 & 2 & 3 & 1 & 2 & 3 & 1 & 2 & 3 & 1 & 2 & 3 & 1 & 2 & 3 \\
\hline SAW value & $\begin{array}{l}\hat{0} \\
\stackrel{0}{+} \\
\stackrel{0}{0}\end{array}$ & $\begin{array}{c}\stackrel{p}{m} \\
\stackrel{m}{m} \\
\stackrel{0}{0}\end{array}$ & $\begin{array}{l}m \\
\infty \\
\stackrel{+}{+} \\
\vdots \\
0\end{array}$ & $\begin{array}{l}m \\
\stackrel{m}{o} \\
\stackrel{q}{0}\end{array}$ & $\underset{\substack{N \\
m \\
0}}{a}$ & 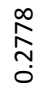 & 芦 & 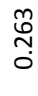 & $\begin{array}{l}\stackrel{0}{0} \\
\stackrel{-1}{+} \\
\stackrel{0}{0}\end{array}$ & \begin{tabular}{l}
$\infty$ \\
$\stackrel{0}{+}$ \\
\multirow{0}{0}{}
\end{tabular} & $\underset{\substack{-1 \\
\tilde{\infty} \\
0}}{0}$ & 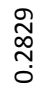 & $\begin{array}{c}\hat{0} \\
\text { m. } \\
\text { o. } \\
\text { d }\end{array}$ & 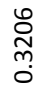 & $\begin{array}{l}\hat{\infty} \\
0 \\
0 \\
0 \\
0\end{array}$ & $\stackrel{\overbrace{}}{\text { m }}$ & $\begin{array}{l}\hat{b} \\
\stackrel{n}{n} \\
0\end{array}$ & 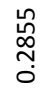 \\
\hline
\end{tabular}
SAW method 
Tab. 2. Results of multicriteria assessment of the second-level indicators of commercial real estate object (office) lease using the SAW method

\begin{tabular}{|c|c|c|c|c|c|c|}
\hline \multirow{2}{*}{$\begin{array}{c}\text { NAME OF } \\
\text { INDICATOR } \\
\text { UNITS }\end{array}$} & \multicolumn{3}{|c|}{ ENVIRONMENT } & \multicolumn{3}{c|}{ PREMISES } \\
\cline { 2 - 7 } & $\mathbf{1}$ & $\mathbf{2}$ & $\mathbf{3}$ & $\mathbf{1}$ & $\mathbf{2}$ & $\mathbf{3}$ \\
\cline { 2 - 7 } & ALTERNATIVES & 0.3332 & 0.3496 & 0.3379 & 0.3124 \\
\hline
\end{tabular}

Tab. 3. Results of the multicriteria assessment for the first-level indicators of the lease of a commercial real estate object (office) using the SAW method

\begin{tabular}{|l|c|c|c|}
\hline \multicolumn{1}{|c|}{ OPTIONS } & FIRST & SECOND & THIRD \\
\hline SAW value & 0.3780 & 0.3186 & 0.261 \\
\hline Rank & first & second & third \\
\hline
\end{tabular}

assessed (there can be dozens of them). Hence, the assessment of lease options provided will only be worthwhile if the calculations are automated. They can be performed by a computerised decision-support system.

\section{CONCLUSIONS}

Today, the company offices are becoming an inherent part of the business that significantly affects the results of the commercial activity. The increasing demand for offices derives from both the internal and external needs. The former arise where the companies establish their affiliates and subsidiaries, expand their business in new areas, improve the office environment, focus their activities on one space, and improve their image; the latter mean the foreign capital. The global investors optimising their business are increasingly interested in the Middle Europe and the Baltic States, and they are gradually turning away from India and Asian countries.

Today, when selecting the premises, a potential tenant considers the aggregate of criteria covering various aspects rather than several basic criteria. In this case, the office lease options are defined by multiple various indicators. To rank such options, the indicators need to be combined in one generalised unit. The multi-criteria methods may be used to resolve such tasks.

The adequacy of the lease option assessment largely depends on the system reflecting their indicators. In the case of a small number of indicators, a single-level system may be used. And in the case of many indicators, the experts cannot accurately assess their weights. The formation of the hierarchical system is a proven method to reduce the number of simultaneously assessed indicators. The hierarchical structure of the lease option indicators was formed on their basis. It consists of three main blocks, i.e. economic, environmental, and premise indicators. The first was assigned 11 indicators, environmental - 16 indicators, and premises -24 indicators. The number of indicators in environmental and premise blocks appeared to be too high in terms of the weight assessment; therefore, they were divided into several parts: the block of environmental indicators - infrastructure and location, and buildings - the technical layout, atmosphere, and options.

The multi-criteria assessment of one of the lease options, based on the hierarchical indicator system, was carried out as follows: first, the multi-criteria assessment values of all six allied indicator groups were determined through the method SAW. They became the values of the blocks combining such groups (infrastructure, location, technical layout, atmosphere, and options). On this basis and the weights of such blocks, the values of the blocks of the previous level (environmental and premises) were determined. During the last stage, based on the weights and values of three main blocks, the generalised multi-criteria assessment of the determined lease option was carried out.

The multicriteria assessment of lease options for commercial real estate objects (offices) requires largescale calculations. They significantly increase if we take dozens of options for consideration. Hence, to make use of the proposed methodology efficiently, a computerised decision-support system needs to be developed.

\section{ACKNOWLEDGEMENTS}

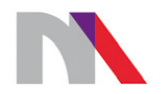

\section{Ministry of Science and Higher Education \\ Republic of Poland}

7th International Conference on Engineering, Project, and Production Management (EPPM2016) was financed in the framework of the contract no. 712/P-DUN/2016 by the 
Ministry of Science and Higher Education from the funds earmarked for the public understanding of science initiatives.

7th International Conference on Engineering, Project, and Production Management (EPPM2016) finansowana w ramach umowy 712/P-DUN/2016 ze środków Ministra Nauki i Szkolnictwa Wyższego przeznaczonych na działalność upowszechniającą naukę.

\section{LITERATURE}

Alonso, W. (1964). Location and Use Toward a General Theory of Land Rent. Harvard University Press.

Čeh, M., Viitanen, K., \& Peruš, I. (2012). A non-parametric CAE approach to office rents: Identification of Helsinki metropolitan area submarkets. Expert Systems with Applications, 39(1), 460-471.

Di Pasquale, D., \& Wheaton, W. (1992). The markets for real estate assets and space: a conceptual framework. American Real Estate and Urban Economics Association, 20, 181-197.

Dunse, N., \& Jones, C. (1998). A hedonic price model of office rents. Journal of Property Valuation and Investment, 16(3), 297-312.

French, N., \& Wiseman, G. (2003). The price of space: the convergence of value in use and value in exchange. Journal of Property Investment \& Finance, 21(1), 23-30.

Ginevičius, R. (2007a). Hierarchical structuring of processes and phenomena. Busines: Theory and Practice, $8(1), 14-18$.

Ginevičius, R. (2007b). Generating a structural system of criteria for describing a complicated phenomenon. Busines: Theory and Practice, 8(2), 68-72.

Ginevičius, R. (2009). Some problems of quantitative evaluation of the state of social-economic system. Busines: Theory and Practice, 10(2), 69-83.

Ginevičius, R., \& Podvezko, V. 2005. Generation of a set evaluation criteria. Business: Theory and Practice, 6(4), 199-207.

Ginevičius, R., Podvezko, V., \& Mikelis, D. (2004). Quantitative evaluation of economic and social development of Lithuanian regions. Ekonomika: mokslo darbai, 65, 67-81.

Hwang, C. L., \& Yoon, K. (1981). Multiple attribute decision making-methods and applications. A state of the art survey. Berlin, Heidelberg, New York: Springer Verlag.

Khamkanya, T., Heaney, G., \& McGreal, S. (2012). Scenariobased approach to office occupancy analysis. Property Management, 30(4), 333-350.

Mills, E. S. (1972). Studies in the structure of the urban economy. Baltimore: The John Hopkins Press.

Muth, R. (1968). Cities and housing. Chicago: University of Chicago Press.

Nase, I., Berry, J., \& Adair, A. (2013). Real estate value and quality design in commercial office properties. Journal of European Real Estate Research, 6(1), 48-62.
Ncube, M., \& Riffat, S. (2012). Developing an indoor environment quality tool for assessment of mechanically ventilated office buildings in the UK - A preliminary study. Building and Environment, 53, 26-33.

Pagourtzi, E., Assimakopoulos, V., Hatzichristos, T., \& French, N. (2003). Real estate appraisal: a review of valuation methods. Journal of Property Investment \& Finance, 21(4), 383-401.

Peng, C., Ali A. S., \& Ahmad, F. (2014). Improving occupants' satisfaction with effective maintenance management of HVAC system in office buildings. Automation in Construction, 43, 31-37.

Podvezko, V. (2008). Comprehensive evaluation of complex quantities. Business: Theory and Practice, 9(3), 160168. doi: 10.3846/1648-0627.2008.9.160-168

Saaty, T. L. (1980). The analytic hierarchy process. New York: McGraw Hill.

Wagner, A., Lützkendorf, T., Voss, K., Spars, G., Maas, A., \& Herke, S. (2014). Performance analysis of commercial buildings. Results and experiences from the German demonstration program 'Energy Optimized Building (EnOB)'. Energy and Buildings, 68, 634-638.

Zhang, X. (2015). Green real estate development in China: State of art and prospect agenda - A review. Renewable and Sustainable Energy Reviews, 47, 1-13. 